\title{
ISOLATION AND MOLECULAR IDENTIFICATION OF INDIGENOUS BACTERIAL ISOLATES ABLE TO DEGRADE ORGANOPHOSPHATES
}

\section{Ghada M. El-sayed ${ }^{1, *}$, Ibrahim ${ }^{2}$ S.A., Nivien. A. Abosereh ${ }^{1}$, Abd El-Razik ${ }^{2}$ A.B.,} Fatma M. Hafez ${ }^{1}$ and Hammad ${ }^{3}$ M.A.

1- Microbial Genetics Dept., National Research Centre., P.O. Box 12622, 33 El-Bohouth St., Dokki, Giza, Egypt

2- Genetic. Dept., Fac. of Agric., Ain Shams Univ., P.O. Box 68, Hadayek Shubra 11241, Cairo, Egypt

3- Plant Protection Dept., Fac. of Agric., Ain Shams Univ., P.O. Box 68, Hadayek Shobra 11241, Cairo, Egypt

*Corresponding author: ghada.khalefa@yahoo.com

\section{ABSTRACT}

The wide and indiscriminate use of pesticides for pest control in agriculture has inflicted serious harm and problems to humans as well as to the biodiversity. Microbial degradation of pesticides in contaminated soils has been considered advantageous to decontaminate areas that have been polluted by pesticides. Chlorpyrifos and diazinon were the most persistent residues in Egyptian soils. Four bacterial isolates were isolated from organophosphorus insecticides contaminated soils and genetically identified based on DNA sequence of $16 \mathrm{~s}$ rDNA gene, Cronobacter muytjensii GH10, Achromobacter xylosoxidans GH9OP, Pseudomonas aeruginosa GH2NO8 and Pseudomonas putida GH4SNO/P were able to degrade $92.59 \%$, $97.75 \%, 91.82 \%$, and $90.78 \%$ of diazinon $(600 \mathrm{mg} / \mathrm{l})$ as compared with $16.99 \%$ in control and $93.43 \%, 78.51 \%, 93.18 \%$ and $95.36 \%$ of chlorpyrifos $(480 \mathrm{mg} / \mathrm{l})$ as compared with $4.28 \%$, in control, respectively after 20 days of incubation.

Keywords: Organophosphates, biodegradation, 16sr DNA gene, Gas chromatography analysis.

\section{INTRODUCTION}

The pesticides extensive use through accidental spills, handling, crop spraying, rinsing of containers, etc. has potential to contaminate soil, air and water (Akbar and Sultan 2016). 38 percent of total global pesticides consumption is accounted by Organophosphorus pesticides which replaced organochlorines to a greater extent against crop loss by pest attack and improving crop yield (Dhanya 2014)

Although (Ops) play important roles in protecting agriculture crop from weeds, insect pests and in disease-transmitting vectors controlling, they irreversibly in activate acetylcholine esterase (AChE) which is essential to nerve function in insects, human and many other animals. Inhibition of acetylcholine esterase results in neurotransmitter acetylcholine accumulation and acetyl choline receptor continued stimulation such; they could cause acute or chronic poising in human being (Zajic and Supplisson 1972).

Chemical treatments, incineration and landfills are the current methods in OPs detoxification (Salman et al 2010). Incineration although the most reliable method for OPs destructions, it has involved a serious public opposition due to the potentially toxic emission (Richins et al 1997). Chemical methods are problematic due to production of large volumes of acids and alkali which subsequently must be disposed. Landfills function adequately but, leaching of pesticides into ground water supplies and surrounding soil is a big issue of concern. 
One of the main methods to resolve the problems of (OPs) residues accumulation is to bioremediate these compounds (Ang et al 2005). OPs contain three phosphoester bonds and hence are often termed phosphotriester. Hydrolysis of only one phosphoester bond (P-O, P-F, P-S and P-CN) can reduce significantly the toxicity of OPs by Utilizing microbial enzymes that is an effective approach to degrade harmful OP compounds (Xie et al 2013). For example the hydrolysis of parathion resulted in 100-fold reduction in toxicity (Lan et al 2006).

Various organophosphorus pesticides degrading bacteria able to use OPs as carbon, nitrogen as an energy source were isolated from pesticides contaminated environments (Hsu et al 2008). Pesticide degrading bacteria are including Flavobacterium sp. (Mulbry and Karns 1989), Pseudomonas diminuta MG (Gilani et al 2016), Penicillium lilacinum BP (Liu et al 2004), Arthobacter sp. (Ohshiro et al 1999). These bacterial strains have the ability to degrade OPs by different types of enzymes. The most characterized enzymes are phosphotriesterase (PTEs). Organophosphorus pesticides are commonly used in Egypt. Some bacterial strains have ability to convert these pesticides into sulfons or oxons or some other degradation products which may be less toxic than the parent molecule (Hill 2003)

The goals of this study were to isolate and identify new bacterial strains from OPS contaminated Egyptian agriculture soils able to degrade and use OPs insecticides as a sole source of carbon. The new isolates from this work may be better suited to the climate and environment conditions in Egypt.

\section{MATERIALS AND METHODS}

\section{Reagents and Chemicals}

Analytical grade chlorpyrifos (48\%) and diazinon $(60 \%)$ emulsifiable concentrate were purchased from (Sinochem Agro.Co.Ltd, China) .All reagents and solvents used in the present study were of analytical grade. Diazinon and chlorpyrifos were used as organophosphorus insecticides models due to their high residues in Egyptian soils (Metwally 2014).

\section{Detection the most persistent organophospho- rus pesticides in the Egyptian soils}

Soil samples from agriculture fields in different governorates, Sharqia, Minufiyah, Qalyubiyah and Giza, Egypt were screened for the purpose of detection of the most persistent pesticides residues by Gas Chromatography analysis in Central Agriculture Pesticides Lab. (CAPL), Agriculture Research Center. Giza, Egypt.

\section{Enrichment and selection of pesticides de- grading bacterial isolates}

Soil samples were transferred to the laboratory and first enriched with access of chlorpyrifos and diazinon which were detected in Egyptian soils in high residues for 10 days after thorough mixing to isolate potent bacterial isolates in organophosphorus pesticides biodegradation. Further enrichments were then carried out in which one gram from previously enriched soils was used to inoculate $50 \mathrm{ml}$ autoclaved minimal salt media (MSM) containing $600 \mathrm{mg} / \mathrm{L}$ diazinon and $480 \mathrm{mg} / \mathrm{L}$ chlorpyrifos as a sole carbon source (Singh 2009). Cultures were then incubated on an orbital shaker at $30^{\circ} \mathrm{C}$ for 5 days at $150 \mathrm{rpm}$.

All cultures were allowed to settle for $2 \mathrm{~h}$ and $5 \mathrm{ml}$ of each supernatant was used to inoculate 45 $\mathrm{ml}$ fresh MSM media containing the same ingredients for additional seven days under the same conditions. Serial dilutions of cultures $10^{-4}$ to $10^{-6}$ were plated on LB agar plates. Plates were incubated at $30^{\circ} \mathrm{C}$ for $18 \mathrm{hs}$.

\section{Degradation of chlorpyrifos and diazinon in minimal salt liquid media}

The bacterial isolates were transferred to MSM media containing diazinon $(600 \mathrm{mg} / \mathrm{l})$ and chlorpyrifos $(480 \mathrm{mg} / \mathrm{l})$ as a sole carbon source. Each sample was prepared in triplicate. All cultures were incubated at $30^{\circ} \mathrm{C}$ and $\mathrm{pH}$ equal 7,8 , and 9 on an orbital shaker (Thermo fisher scientific, UK) at $150 \mathrm{rpm}$. At the same time Non-inoculated media were also run in parallel to the other cultures as control. Samples were taken after 0, 5, 10, 15 and 20 days of incubation, the residual diazinon and chlorpyrifos were determined in the culture extract of the bacterial isolates and measured using gas chromatography (GC) analysis (Dhanya 2014). 
to degrade organophosphates

\section{Extraction of genomic DNA from bacterial iso- lates}

The isolated bacteria were cultured in conical flasks (Pyrex, USA) containing $20 \mathrm{ml}$ LB medium by shaking in an orbital shaker (Thermo fisher scientific, UK) at $180 \mathrm{rpm}$ for $18 \mathrm{~h}$. The cultures were centrifuged at $13,000 \mathrm{rpm}$ for $5 \mathrm{~min}$ at $4^{\circ} \mathrm{C}$. The pellets were subjected to genomic DNA extraction using the (QIAamp DNA Mini Kit, QIAGEN, Germany). The extracted DNA was used as a template for PCR to amplify $16 \mathrm{~S}$ rDNA gene.

Molecular identification of bacterial isolates by PCR amplification and sequencing of 16S rDNA gene

Molecular tools such as 16S rDNA pcr amplification were used to identify the bacterial isolates (Hoffman et al 2010). Bacterial 16S rDNA was amplified by PCR using the universal primers; forward primer sequence (5'AGAGTTTGATCCT GGCTCAG3') and reverse primer sequence (5'CTACGGCTACCTTGTTACGA3') thereby producing an amplicon of $\sim 1500 \mathrm{bp}$. Amplification was carried out in $50 \mu \mathrm{l}$ reactions by using a PCR master mix kit (Qiagen, Germany) according to the manufacturer's instructions using a GeneAmp PCR System 2400 Thermal cycler (Perkin-Elmer Norwalk, Connecticut, USA). The following program was used: $94^{\circ} \mathrm{C}$ for 3 min as initial denaturation step followed by 35 cycles of denaturation at $94^{\circ} \mathrm{C}$ for $30 \mathrm{sec}$, annealing at $55^{\circ} \mathrm{C}$ for $1 \mathrm{~min}$, extension at $72^{\circ} \mathrm{C}$ for $2 \mathrm{~min}$ and final extension at $72^{\circ} \mathrm{C}$ for 10 min. PCR product was purified by QIAquick Gel Extraction Kit (Qiagen, Germany) following the protocol provided by the supplier and then resolved by electrophoresis on $1.5 \%$ agarose gel. Nucleotide sequence was determined using the same Primers with the dideoxy-chain termination method. The obtained sequences were analyzed for similarities to other known sequences found in the GenBank database using BLAST program of the NCBI database.

\section{RESULTS AND DISCUSSION}

Detection the most persistent pesticides residues in the Egyptian soil samples

In soil samples under study, Diazinon and chlorpyrifos as organophosphorus pesticides showed higher concentrations than that of other detected pesticides such as Oxamyl and pirimiphos methyl. Chlorpyrifos recorded $0.07 \mathrm{mg} / \mathrm{kg}$ soil in Beheira and Minufiyah but it recorded 0.09 $\mathrm{mg} / \mathrm{kg}$ soil in Qalyubiyah. Diazinon concentration ranged between $0.008 \mathrm{mg} / \mathrm{kg}$ soil in Kaliopia to $0.08 \mathrm{mg} / \mathrm{kg}$ soil in Beheira Table (1). These results were agreed with Metwall (2014), he discovered that organophosphorus pesticides, diazinon and chlorpyrifos were the most persistent residues in different Egyptian soils.

Table 1. The concentrations of pesticides residues in soil samples

\begin{tabular}{|c|c|c|}
\hline $\begin{array}{l}\text { Soil sample } \\
\text { locations }\end{array}$ & $\begin{array}{l}\text { Detected } \\
\text { pesticides } \\
\text { residues }\end{array}$ & $\begin{array}{c}\text { Concentration } / \mathrm{kg} \\
\text { soil }\end{array}$ \\
\hline \multirow{4}{*}{ Giza } & Chlorpyrifos & 0.01 \\
\hline & Oxamyl & 0.002 \\
\hline & Adicarb & 0.004 \\
\hline & Diazinon & 0.02 \\
\hline \multirow{2}{*}{ Sharqia } & Oxamyl & 0.004 \\
\hline & Chlorpyrifos & 0.05 \\
\hline \multirow{3}{*}{ Beheira } & $\begin{array}{c}\text { Chlorpyrifos } \\
\text { methyl }\end{array}$ & 0.07 \\
\hline & Oxamyl & 0.007 \\
\hline & Diazinon & 0.08 \\
\hline \multirow{3}{*}{ Kaliopia } & Oxamyl & 0.004 \\
\hline & Chlorpyrifos & 0.09 \\
\hline & Diazinon & 0.008 \\
\hline \multirow{3}{*}{ Monofia } & $\begin{array}{l}\text { pirimiphos } \\
\text { methyl }\end{array}$ & 0.006 \\
\hline & Diazinon & 0.04 \\
\hline & Chlorpyrifos & 0.07 \\
\hline
\end{tabular}

Isolation of potent organophosphorus degrading bacterial isolates

Few bacterial isolates capable of degrading organophosphorus pesticides have been reported till date. Four different aerobic bacterial isolates capable of degrading chlorpyrifos of initial concentration $(480 \mathrm{mg} / \mathrm{l})$ and diazinon of initial concentration $(600 \mathrm{mg} / \mathrm{l})$ by the enrichment technique were developed from five soil samples collected from various agricultural fields. These four bacterial isolates labeled as, GH10, GH2NO8, GH9OP and GH4SNO/P have showed good growth on minimal salt media containing diazinon and chlorpyrifos with concentrations mentioned previously after 5 days at $\mathrm{pH} 8$ Fig. $(\mathbf{1}, \mathbf{2})$. 


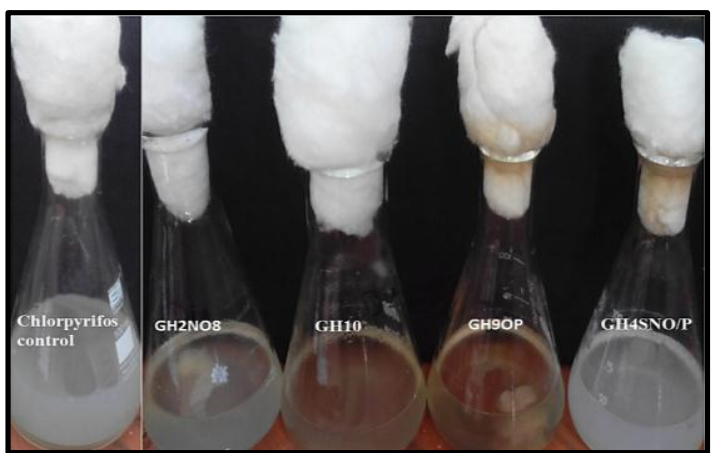

Fig. 1. Growth of bacterial isolates on liquid minimal salt media containing chlorpyrifos $(480 \mathrm{mg} / \mathrm{l}$ ) after 5 days incubation. GH9OP, GH2NO8, GH10 and $\mathrm{GH} 4 \mathrm{SNO} / \mathrm{P}$ were the bacterial isolates; Control: liquid MSM with chlorpyrifos $(480 \mathrm{mg} / \mathrm{l})$ without bacterial inoculums

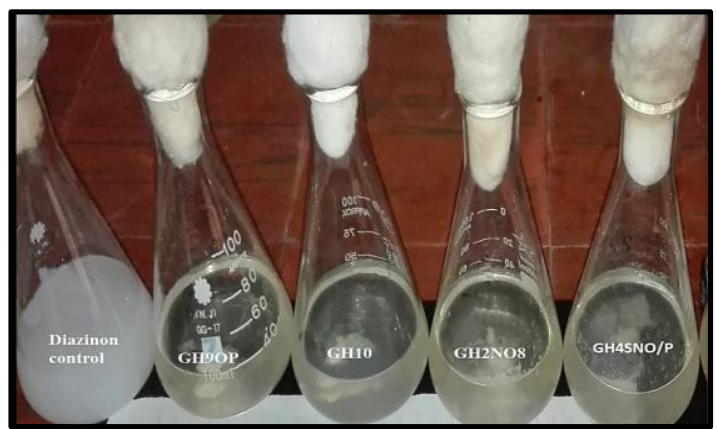

Fig. 2. Growth of bacterial isolates on liquid minimal salt media containing diazinon $(600 \mathrm{mg} / \mathrm{l})$ after 5 days incubation. GH9OP, GH2NO8, GH10 and $\mathrm{GH} 4 \mathrm{SNO} / \mathrm{P}$ are the bacterial isolates; Control: liquid MSM with diazinon (600 $\mathrm{mg} / \mathrm{l})$ but no bacterial inoculums.

Molecular identification of OPs degrading bacterial isolates by PCR amplification of the $16 \mathrm{~S}$ rDNA

16s rDNA gene universal primers amplify $\sim 1550$ bp for all bacterial isolates (Fig 3). Partial sequences were analyzed, bacterial isolate $\mathrm{GH} 10$ 16 s rDNA gene partial sequence has $99 \%$ similarity with that of Cronobacter muytjensii strain ATCC 51329 accession no. CP012268. Bacterial isolate $\mathrm{GH} 10$ was named as Cronobacter muytjensii strain GH10. 16s rDNA gene partial sequence of GH2NO8 bacterial isolate has $100 \%$ similarity with that of Pseudomonas aeruginosa strain GHJ12 accession no. MG396955. GH2NO8 bacterial isolate was identified as Pseudomonas aeruginosa strain GH2NO8. 16s rDNA gene partial sequence of bacterial isolate GH9OP has $100 \%$ similarity with that of Achromobacter xylosoxidans strain NCCP-44 accession no. AB547225 Thus it was identified as Achromobacter xylosoxidans strain GH9OP. With respect to the GH4SNO/P bacterial isolate, its 16s rDNA gene partial sequence has 99\% similarity with that of Pseudomonas putida strain JR4 accession no. KY982927. This strain was named as Pseudomonas putida strain GH4SNO/P. 16s rDNA genes partial sequences of bacterial isolates were deposited in the GenBank database with accession numbers shown in Table (2).

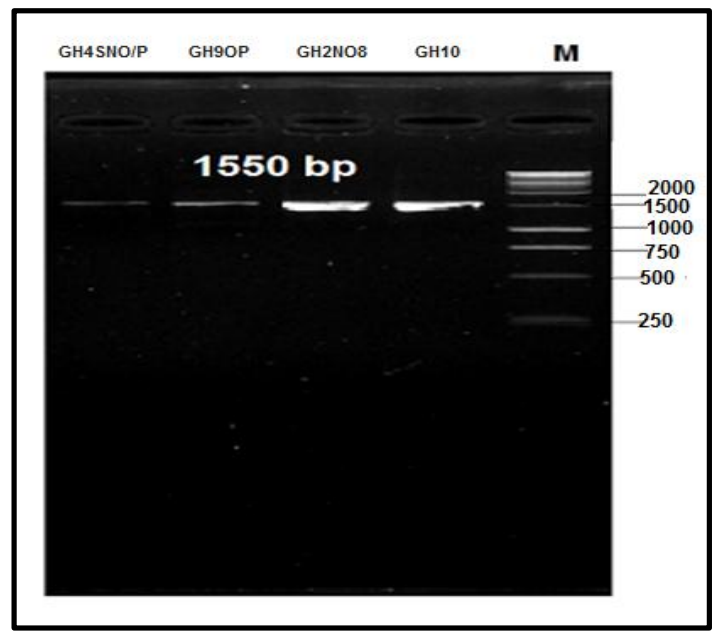

Fig. 3. Agarose gel electrophoresis for PCR product of $16 \mathrm{~s}$ rDNA gene. M: $1 \mathrm{~Kb}$ DNA ladder (Thermoscientific, Germany)

Table 2. Accession numbers of $16 \mathrm{~s}$ rDNA gene of bacterial isolates

\begin{tabular}{|c|c|c|}
\hline $\begin{array}{l}\text { Bacterial } \\
\text { isolates } \\
\text { codes }\end{array}$ & $\begin{array}{c}\text { Molecular } \\
\text { identification }\end{array}$ & $\begin{array}{c}\text { Accession } \\
\text { number }\end{array}$ \\
\hline $\mathrm{GH} 10$ & $\begin{array}{l}\text { Cronobacter } \\
\text { muytjensii } \\
\text { strain GH10 }\end{array}$ & KY945346 \\
\hline GH2NO8 & $\begin{array}{l}\text { Pseudomonas } \\
\text { aeruginosa } \\
\text { strain GH2NO8 }\end{array}$ & KY945349 \\
\hline GH9OP & $\begin{array}{l}\text { Achromobacter } \\
\text { xylosoxidans } \\
\text { strain GH9OP }\end{array}$ & KY945347 \\
\hline GH4SNO/P & $\begin{array}{l}\text { Pseudomonas } \\
\text { putida strain } \\
\text { GH4SNO/P }\end{array}$ & KY945348 \\
\hline
\end{tabular}




\section{Degradation of diazinon and chlorpyrifos in liquid MSM by bacterial isolates}

Cronobacter muytjensii strain $\mathrm{GH} 10$ was able to degrade $92.59 \%$ of diazinon as compared to $16.99 \%$ in control and $93.43 \%$ of chlorpyrifos as compared to $4.28 \%$ in control after 20 days of incubation Fig. (4). This search has been the first study that manipulates Cronobacter muytjensii in pesticides biodegradation where this bacterial isolate showed a remarkable biodegradation activity.

There was a considerable removal of diazinon and chlorpyrifos by Pseudomonas aeruginosa strain GH2NO8, Achromobacter xylosoxidans strain GH9OP and Pseudomonas putida strain GH4SNO/P. They were able to degrade $91.82 \%$, $97.75 \%$ and $90.78 \%$ respectively of the former as compared to $16.99 \%$ in control. With respect to chlorpyrifos biodegradation, these bacterial isolates exhibited the ability to remove $78.51 \%$, $93.18 \%$ and $95.36 \%$ as compared to $4.28 \%$ in control after 20 days of incubation Fig. (5, 6, 7). Diazinon and chlorpyrifos control biodegradation was shown in Fig. (8). In diazinon biodegradation, Achromobacter xylosoxidans strain GH9OP showed the highest degradation, but in Case of chlorpyrifos biodegradation, Pseudomonas putida strain GH4SNO/P recorded the highest degradation. These results are in consistent with the previous reports, where bacterial strain Achromobacter xylosoxidans (JCp4) and Ochrobacterum sp. (FCp1) were able to degrade chlorpyrifos in sterilized and non-sterilized soils, they exhibited the ability to degrade $93 \%$ to $100 \%$ of the input concentration $200 \mathrm{mg} / \mathrm{l}$ within 42 days (Akbar and Sultan 2016). In this study, Achromobacter $x y$ losoxidans strain GH9OP is a promising candidate for raising the productivity of crops in pesticides contaminated soils. Many bacterial strains are involved in organophosphorus pesticides degradation, among these bacteria are Enterobacter $s p$. (Singh et al 2004), pleismonas sp. (Zheng et al 2013), Agrobacterium radiobacter (Horne et al 2002) and Streptomyces sp. (Nelson 1982). These results are agreed with that obtained by Khani and Kafilzadeh (2015), they isolated Pseudomonas aeruginosa and Flavobacterium $s p$. which were able to reduce the level of diazinon at level of $p \leq$ 0.05 . Khalid et al (2016) isolated bacterial strain Pseudomonas putida CP-1, this bacterium was able to hydrolyze the phosphotriester bonds in chlorpyrifos. Moreover Pseudomonas putida MAS1 able to degrade chlorpyrifos was isolated by Ajaz et al (2009). The metabolic specificity of OP degrading microorganisms, however, is determined by the chemical resemblance among the OP compounds. Both insecticides tested in this work have phosphotriester bond in their molecular structures, suggesting that hydrolysis at this bond takes place.
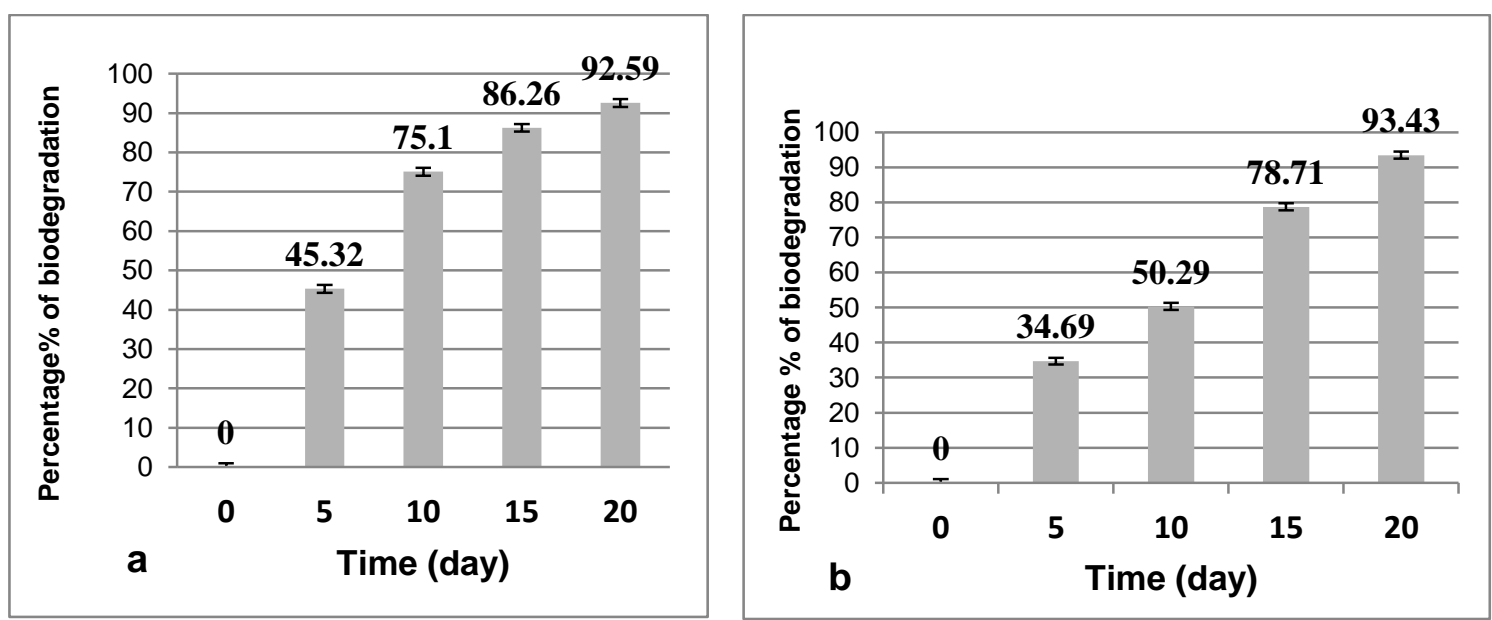

Fig. 4. (a): biodegradation Percentage of diazinon $(600 \mathrm{mg} / \mathrm{l})$ and (b): Biodegradation of chlorpyrifos (480 $\mathrm{mg} / \mathrm{l})$ by Cronobacter muytjensii strain $\mathrm{GH} 10$ 


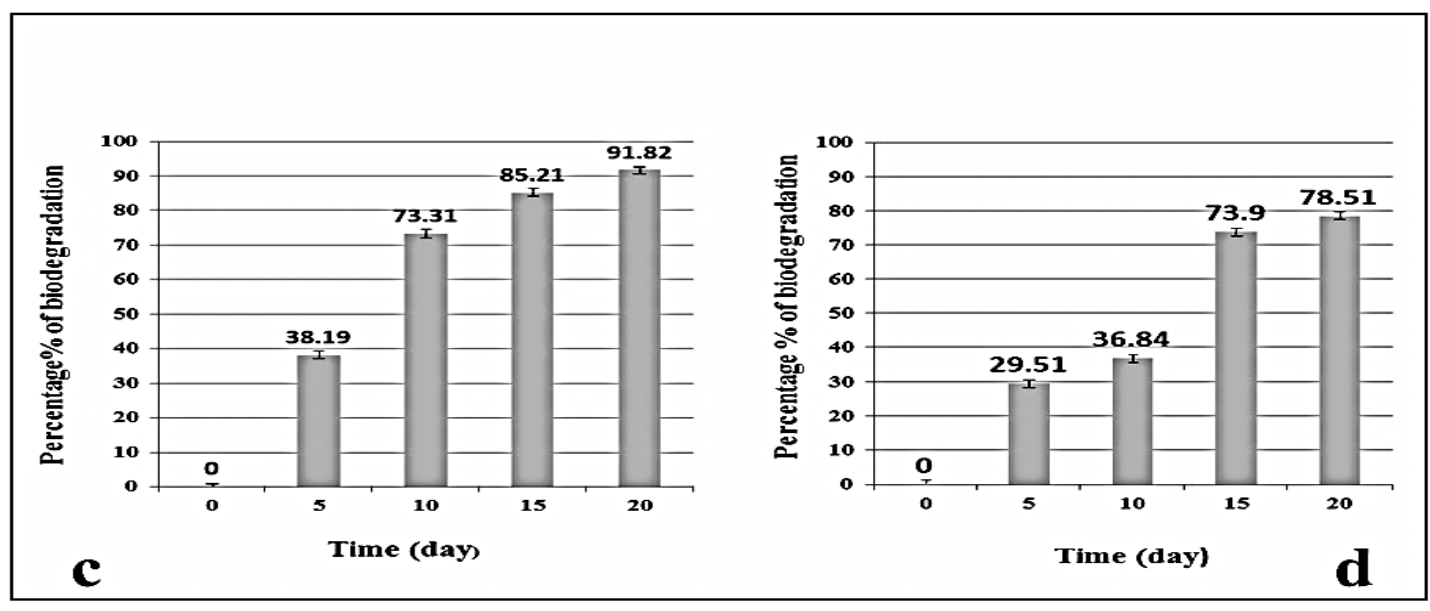

Fig. 5. (c): Percentage of biodegradation of diazinon (600 mg/l) and (d): Biodegradation of chlorpyrifos (480 mg/l) by Pseudomonas aeruginosa strain GH2NO8

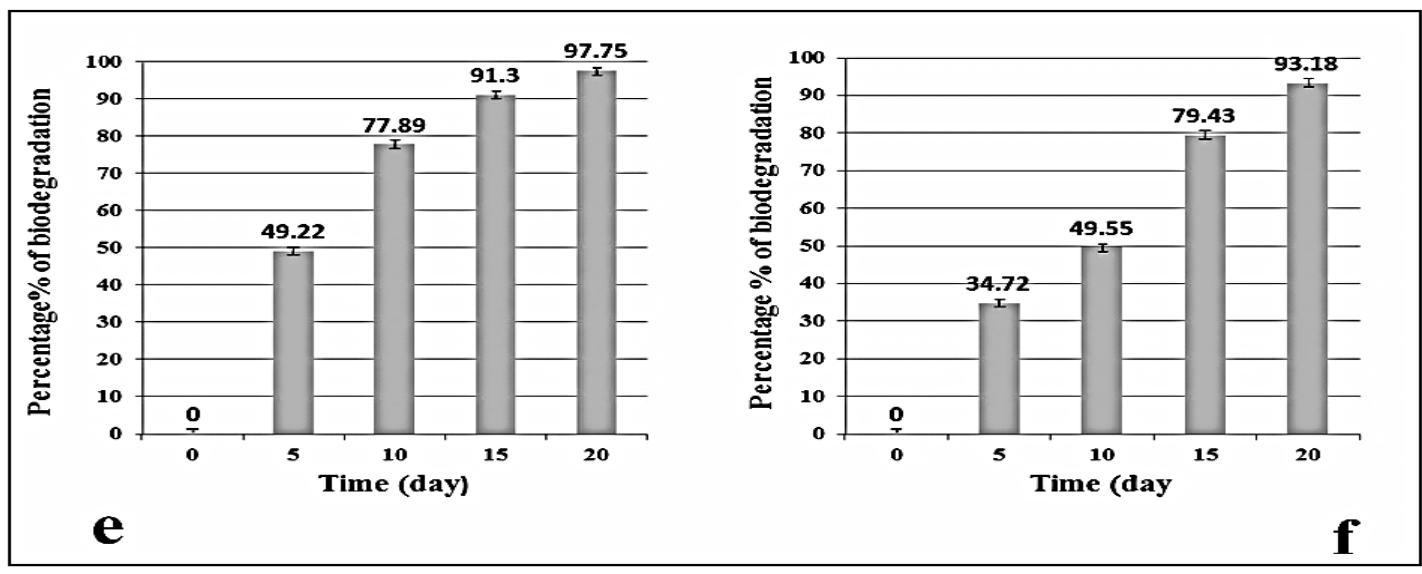

Fig. 6. (e): Percentage of biodegradation of diazinon (600 mg/l) and (f): Biodegradation of chlorpyrifos (480 mg/l) by Achromobacter xylosoxidans strain GH9OP
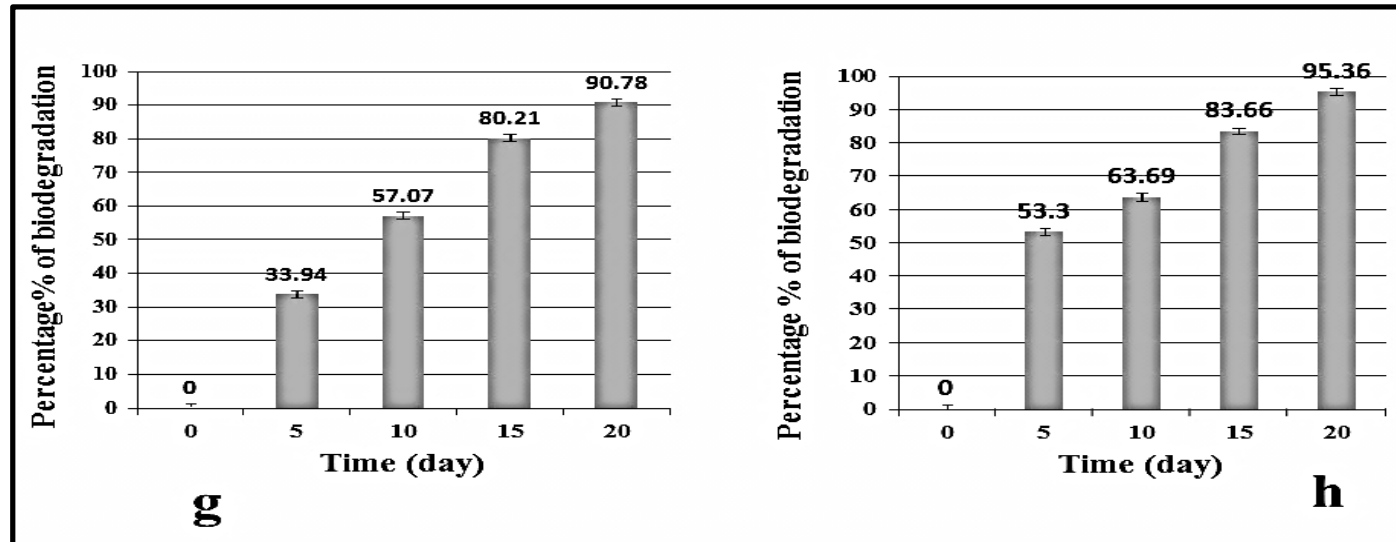

Fig. 7. (g): Percentage of biodegradation of diazinon (600 mg/l) and (h): Biodegradation of chlorpyrifos (480 mg/l) by Pseudomonas putida strain GH4SNO/P 


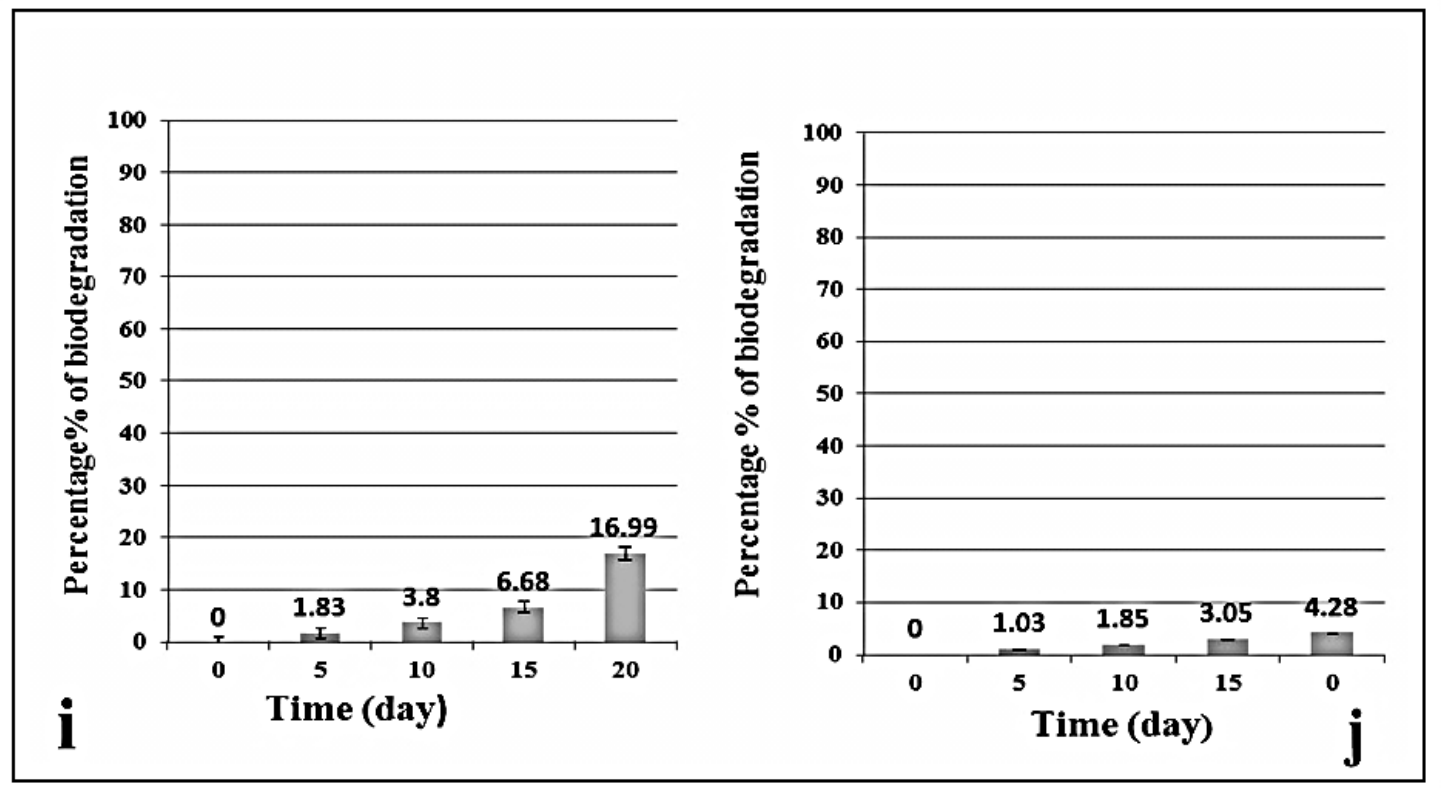

Fig. 8. (i): Percentage of biodegradation of diazinon $(600 \mathrm{mg} / \mathrm{l})$ and (j): Biodegradation of chlorpyrifos $(480 \mathrm{mg} / \mathrm{l})$ in control media

\section{CONCLUSION}

Chlorpyrifos and diazinon represented the major organophosphorus pesticides residues in Egyptian soils. Four bacterial isolates, Cronobacter muytjensii strain $\mathrm{GH} 10$, Pseudomonas aeruginosa strain GH2NO8, Achromobacter xylosoxidans strain GH9OP and Pseudomonas putida strain GH4SNO/P improved high activity in organophosphates biodegradation and that makes them potent candidates in organophosphates detoxification in contaminated niches.

\section{ACKNOWLEDGEMNT}

The authors would like to thank Prof. Dr. Hend Abd Allah Mahmoud, senior researcher in Central agriculture pesticides laboratory, Agriculture Microbiology Research Department for her supporting to accomplish of this work.

\section{REFERENCES}

Ajaz M., Jabeen N., Ali T.A. and Rasool S.A. 2009. Split role of plasmid genes in the degradation of chlorpyrifos by indigenously isolated Pseudomonas putida MAS-1. Pak. J. Bot. 41, 2055-2060.
Akbar S. and Sultan S. 2016. Soil bacteria showing a potential of chlorpyrifos degradation and plant growth enhancement. Braz. J. Microbiol. 47, 563-570.

Ang E.L., Zhao H. and Obbard J.P. 2005. Recent advances in the bioremediation of persistent organic pollutants via bimolecular engineering. Enzyme Microbial. Technol. 37, 487-496.

Dhanya M.S. 2014. Advances in microbial biodegradation of chlorpyrifos. J. Environ. Res. Develop. 9, 232-240.

Gilani R.A., Rafique M., Rehman A., M.F. Munis M.F. and Rehman S.U. 2016. Biodegradation of chlorpyrifos by bacterial genus Pseudomonas. J. Basic. Microbiol. 56, 105-119.

Hill E.F. 2003. Wild life toxicology of organophosphorus and carbamate pesticides. In: Handbook of Ecotoxicology, B.A.; Hoffman, G.A. Rattner; J.r. Burton and J.r. Cairns. (eds.). Lewis Publishers, Boca Raton. pp. 281-312

Hoffmann M., Eric W.B., Peter C., Christine E., Markus F. and Steven R.M. 2010. PCR-based method for targeting 16S-23S rRNA intergenic spacer regions among Vibrio species. BMC Microbiology. 90, 2-14.

Horne I., Sutherland T.D., Harcourt R.L., RussellR. J. and Oakeshott J.G. 2002. Identification of an opd (organophosphate degradation) gene in an Agrobacterium isolate. Appl. Environ. Microbiol. 68, 3371-3376. 
Hsu Y.T., Su C.Y., Du H.C., Jao S.C. and Li W.S. 2008. Evaluation of organophosphorus chemicals-degrading enzymes: a comparison of Escherichia coli and human cytosolic amino peptidase. P. Chem. Biodivers. 5, 1401-1411.

Khalid M., Rasul S., Hussain J., Ahmad R., Zia A., Bilal M., Pervez A. and Naqvi T.A. 2016. Biodegradation of Organophosphorus Insecticides Chlorpyrifos by Pseudomonas putida CP. 1. Pakistan J. Zool. 48, 1453-1458.

Khani M. and Kafilzadeh F. 2015. Diazinon degradation by Pseudomonas aeruginosa and Flavobacterium bacteria and assessing the growth Kinetics. J. Biol. Today's World. 4, 4448.

Lan W.S., Gu J.D., Zhang J.L., Shen B.C., Jiang H., Mulchandani A., Chen W. and Qiao C.L. 2006. Coexpression of two detoxifying pesticide-degrading enzymes in a genetically engineered bacterium. Int. Biodeter. Biodegrad. 58, 70-76.

Liu Y., Liu Y., Chen Z., Lian J., Huang X. and Chung Y. 2004. Purification and characterization of a novel organophosphorus pesticide hydrolase from Penicillium lilacinum BP303. Enzyme and Microbial Technology. 34, 297303.

Metwally I.M.G. 2014. Bioremediation of water contamination with pesticides. Ph.D Thesis in agriculture science., department of environmental and bio-agriculture Fac. Agric., Al-Azhar univ., Cairo, Egypt, 86 p.

Mulbry W.W. and Karns J.S. 1989. Parathion hydrolase specified by the Flavobacterium opd gene: relationship between the gene and protein. J. Bacteriol. 171, 6740-6746.
Nelson L.M. 1982. Biologically-induced hydrolysis of parathion in soil and Isolation of hydrolyzing bacteria. Soil Biol. Biochem. 14, 219-222.

Ohshiro K., Kakuta T., Nikaido N., Watanabe T. and Uchiyama T. 1999. Molecular cloning and nucleotide sequencing of organophosphorus insecticide hydrolase gene from Arthrobacter sp. strain B-5. J. Biosci. Bioeng. 87, 531-534.

Richins R.D., Kaneva I., Mulchandani A. and Chen W. 1997. Biodegrading of organophosphorus pesticides by surface expressed organophosphorus hydrolase. Nat. Biotechnol. 15, 984-987.

Salman A., Fard A.T., Nasir A. and Bokhari H. 2010. Comparative analysis of organophosphate degrading enzymes from diverse species. Bioinformation. 5, 67-72.

Singh B.K. 2009. organophosphorus-degrading bacteria: ecology and industrial application. Nature Reviews Microbiology. 7, 156-164.

Singh B.K., Walker A., Morgan J.A. and Wright D.J. 2004. Biodegradation of chlorpyrifos by Enterobacter strain B-14 and its use in bioremediation of contaminated soils. Appl. Environ. Microbiol. 70, 4855-4863.

Xie J., Zhao Y., Zhang H., Liu Z. and Lu Z. 2013. Improving methyl parathion hydrolase to enhance its chlorpyrifos-hydrolysing efficiency. Letters in Applied Microbiology. 58, 53-59.

Zajic E. and Supplisson B. 1972. Emulsification and degradation of Banker C; fuel oil by microorganisms. Biotechnol. Bioeng. 14, 331-343.

Zheng Y., Long L., Fan Y., Gan J., Fang J. and Jin W. 2013. A review on the detoxification of organophosphorus compounds by microorganisms. Afr. J. Microbiol. Res. 7, 2127-2134. 
مجلة اتحاد الجامعات العربية للعظوم الزراعية ، جامعة عين شمس ، القاهرة ، مصر

مجلا(26)، عدد(2D)، عدد خاص، 2511-2503، 2019

Website: http://strategy-plan.asu.edu.eg/AUJASCI/

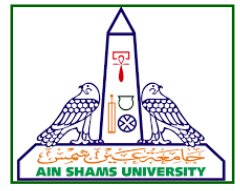

2511

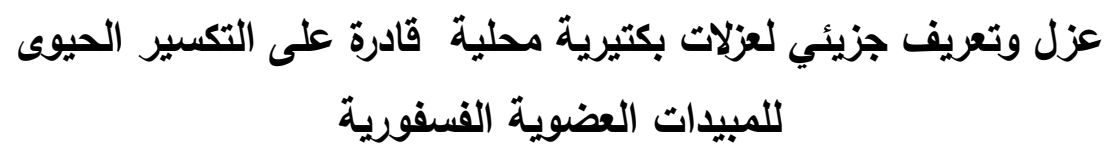

[184]

غادة مصطفى السيد ${ }^{1}$ سمير عبدالعزيز إبراهيم²- نيفين عبدالرحمن أبوسريع 1- أِشرف بكري عبدالرازق

فاطمة ممدوح حافظ - ماهر عبدالعليم حماد 3

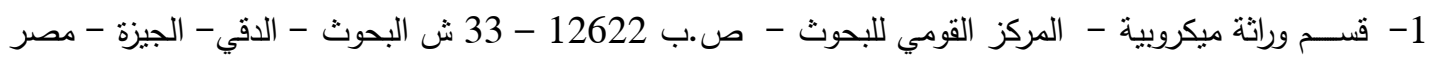

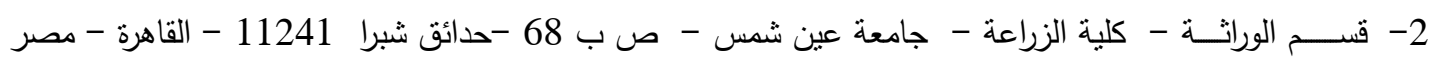

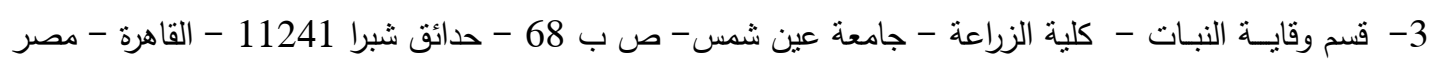

*Corresponding author: ghada.khalefa@yahoo.com

Received 9 August, 2018

Accepted 28 August, 2018

كانت قدرة هذه السلالات فى تكسير الديازينون

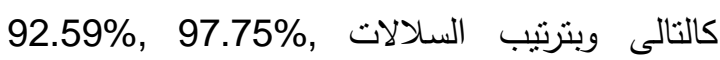

91.82\%, and 90.78\% مقارنة بتكسيره بنسبة

$$
16.99 \text { فى البيئة بدون بكتيريا. }
$$

أما فى حالة الكلوربيريفوس فكان نسبة تحلة فله بهذها.

93.43\%, السلالات كالتالى وبنفس ترتيب السلالات

78.51\%, 93.18\% and 95.36\% مقارنة بنسبة

تحلل ,4.28\% فى البيئة التى لا تحتوى بكتيريا وذلك

بعد عشرين يوما من التحضين حيث استخدم الديازينون

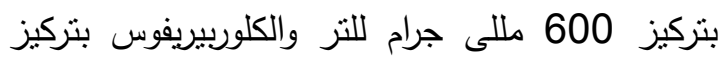

$$
480 \text { مللى جرام للتر . }
$$

الكلمات الدالة: المركبات العضوية الفسفورية، التحلل

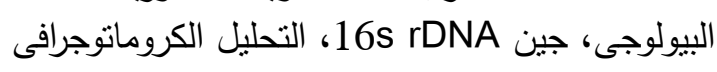

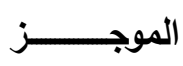

تم تحديد أكثر المبيدات نراكما فى أربعة أنواع

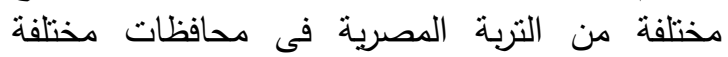

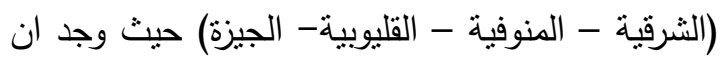

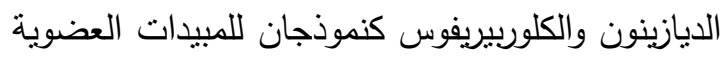

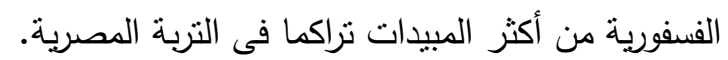

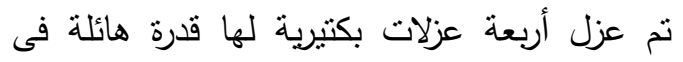

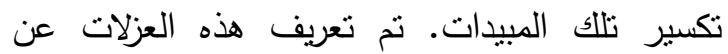

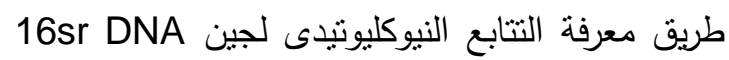
وبقارنة هذه التتابعات بناتلك الموجودة بينك التئك الجينات

Cronobacter muytjensii $\mathrm{GH} 10$

$$
\text { عرفت هذه السلالات بـ }
$$

Achromobacter xylosoxidans GH9OP

Pseudomonas aeruginosa GHNO8

Pseudomonas putida GH4SNO/P 